\title{
OPTIMALISASI PEMANFAATAN SUMBER DAYA AIR UNTUK MENINGKATKAN KINERJA KEUANGAN CV TIRTA BUANA
}

\author{
Ryan Elfahmi *)
}

\author{
*)dosen universitas pamulang, email : ryan.elfahmi@gmail.com
}

\section{ARTICLES INFORMATION}

JURNAL SEKURITAS

(Saham, Ekonomi, Keuangan dan Investasi )

Vol.1, No.3, Maret 2018

Halaman : $107-123$

C LPPM \& Prodi Manajemen

UNVERSITAS PAMULANG

ISSN (online) : 2581-2777

ISSN (print) : :2581-2696

\section{Keyword :}

Optimalisasi, pemanfaatan sumber daya air, kinerja keuangan.

JEL. classification :

C13, G11, G17,L25, L26,

N55, O13, O22, Q25, Y10

\section{Contact Author :}

\section{PRODI MANAJEMEN UNPAM}

JL.Surya Kencana No.1 Pamulang

Tangerang Selatan - Banten

Telp. (021) 7412566, Fax (021) 7412491 Email :

jurnalfinance.unpam@gmail.com
Penelitian dilakukan pada CV Tirta Buana dengan cakupan wilayah survei untuk mendapatkan data-data pemasaran meliputi Kabupaten Bandung Barat, Kota Cimahi, Kota Bandung dan Kabupaten Bandung. Hasil penelitian: 1)Optimalisasi pemanfaatan sumber daya air berdasarkan kapasitas terpasang dengan mengembangkan bisnis air minum dalam kemasan galon sangat layak direalisasikan khususnya berdasarkan kajian aspek keuangan yang meliputi Payback Period=10 bulan dari batas maksimum 45 bulan, NPV=500.171.287, $\mathrm{Pl}=1,78$ dan $\mathrm{IRR}>90 \%$. Optimalisasi juga sangat tepat dilakukan karena dapat meningkatkan nilai ekonomis sumber daya air. Hal tersebut ditunjukkan oleh nilai ekonomis air dari Rp0.76,- per liter (bisnis air bersih perumahan) menjadi Rp118,- per liter. 2)Bisnis air minum dalam kemasan galon dapat meningkatkan kinerja keuangan CV Tirta Buana secara signifikan, hal ini dapat dilihat dari peningkatan current ratio, peningkatan cash ratio, penurunan total debt to equity ratio, penurunan total debt to total capital assets, peningkatan rate of return on investment, peningkatan rate of return on net worth, dan peningkatan total assets turnover.

The study was conducted at the company's CV Tirta Buana with coverage of surveys to obtain marketing data covering West Bandung Regency, Cimahi, Bandung and Bandung Regency. The analytical method used is a financial analysis that includes Payback Period analysis, Net Present Value (NPV), profitability index (PI), Internal Rate of Return (IRR), and analysis of financial performance including analysis of liquidity ratios, solvency ratios and profitability ratios. Results of the study: 1)Optimizing the utilization of water resources based on installed capacity by developing business of drinking water of gallon packing is a very decent realized especially by the financial aspects of the study, include the Payback Period $=10$ months of maximum 45 months, $N P V=500.171 .287, P I=1.78$ and IRR> $90 \%$. Optimizing is also appropriate because it can increase the economic value of water resources, from Rp0.76,-- per liter (residential water business) to Rp118,- per liter. 2)Business of drinking water in gallon packing can improve the financial performance of CV Tirta Buana significantly, it can be seen from the increase in the current ratio, the increase in the cash ratio, a decrease in total debt to equity ratio, a decrease in total debt to total capital assets, an increase in the rate of return on investment, an increase in the rate of return on net worth, and an increase in total asset turnover. 


\section{A. Pendahuluan}

Air memiliki banyak manfaat bagi manusia. Kebutuhan air minum yang berkualitas dan kesadaran bahwa kualitas air tanah di lingkungan perumahan pada umumnya tidak memenuhi standar sebagai air baku untuk kebutuhan air minum dan masak, ditambah dengan kebiasaan sebagian besar masyarakat terutama kalangan pekerja/pegawai yang lebih menyukai kepraktisan dalam mengkonsumsi air minum. Kondisi-kondisi tersebut menjadi faktor utama tingginya permintaan air minum dalam kemasan khususnya air minum dalam kemasan galon dan membuka peluang yang sangat baik bagi wirausaha lokal untuk berbisnis dalam bidang tersebut. Salah satu perusahaan yang bergerak dalam pengelolaan air bersih adalah CV Tirta Buana. CV Tirta Buana melayani kebutuhan air bersih pelanggannya dengan cara mengalirkan air bersih tersebut langsung ke rumahrumah pelanggan. Saat ini, terdapat beberapa aset fisik perusahaan yang perlu mendapatkan perhatian khusus, yaitu:

1. Volume air yang bisa dimanfaatkan masih jauh lebih besar dibandingkan volume air yang dipakai oleh pelanggan.

2. Berdasarkan hasil pemeriksaan laboratorium, kualitas air yang cukup bagus yang memenuhi persyaratan kualitas air baku untuk air minum dalam kemasan.

Dipandang dari sudut bisnis, pertumbuhan CV Tirta Buana di masa yang akan datang dengan cara yang sama tidak menjanjikan. Penambahan pelanggan baru tidak dimungkinkan dengan fasilitas pipa yang ada. Selain itu penambahan saluran baru sulit untuk diwujudkan karena faktor sosial dan kemasyarakatan yang tidak mendukung. Penambahan jaringan pipa utama yang baru akan menghadapi kendala perijinan nonformal (ijin lewat masyarakat), ijin ini memberikan potensi masalah yang besar dan penyelesaiannya membutuhkan biaya nonformal yang besar. Disisi lain, daya beli masyarakat juga kurang sehingga memberi batasan bagi perusahaan dalam menentukan biaya pasang baru. Perusahaan sudah beroperasi selama hampir 10 tahun, dan saat ini pertumbuhan perusahaan secara finansial sudah mulai konstan. Tidak banyak peningkatan pemasukan perusahaan di tahun ini dibandingkan beberapa tahun lalu. Dengan asumsi mempertahankan kondisi yang ada, satu-satunya cara meningkatkan pemasukan perusahaan tiap bulan adalah dengan menaikkan tarif, dan ini merupakan cara yang riskan mengingat faktor sosial memiliki pengaruh sangat kuat di bisnis ini. Oleh karena itu, untuk bisa tetap tumbuh dan berkembang secara bisnis dengan mengoptimalkan pemanfaatan sumber daya yang dimiliki, perusahaan harus bisa memproduksi produk lain yang lebih potensial dan prospektif. Bisnis air minum dalam kemasan galon merupakan bisnis yang cocok direalisasikan CV Tirta Buana dalam usahanya untuk meningkatkan kinerja dan pertumbuhan perusahaan khususnya dalam meningkatkan kinerja keuangan perusahaan, maka perlu diteliti tentang optimalisasi pemanfaatan sumber daya air untuk meningkatkan kinerja keuangan CV Tirta Buana.

\section{B. Perumusan Masalah}

1. Bagaimanakah optimalisasi pemanfaatan sumber daya air berdasarkan kapasitas terpasang dengan mendirikan bisnis air minum dalam kemasan galon layak direalisasikan berdasarkan kajian aspek keuangan?

2. Bagaimanakah kinerja keuangan pada perusahaan setelah adanya optimalisasi pemanfaatan sumber daya air berdasarkan kapasitas terpasang dengan tambahan bisnis baru air minum dalam kemasan galon? 


\section{Tujuan Penelitian}

1. Mengetahui optimalisasi pemanfaatan sumber daya air berdasarkan kapasitas terpasang dengan mendirikan bisnis air minum dalam kemasan galon dan kelayakannya untuk direalisasikan berdasarkan kajian aspek keuangan

2. Mengetahui kinerja keuangan pada perusahaan setelah adanya optimalisasi pemanfaatan sumber daya air berdasarkan kapasitas terpasang dengan tambahan bisnis baru air minum dalam kemasan galon

\section{Landasan Teori}

\section{D.1 Sumber Daya Air}

Fauzi (2004:2) mendefinisikan ilmu ekonomi sumber daya alam sebagai ilmu yang mempelajari pengalokasian sumber daya alam seperti air, lahan, hutan. Secara eksplisit ilmu ini mencari jawaban seberapa besar sumber daya harus diekstraksi, sehingga menghasilkan manfaat yang sebesar-besarnya bagi masyarakat.

Air merupakan sumber daya alam yang diperlukan untuk hajat hidup orang banyak, bahkan oleh semua makhluk hidup. Air yang digunakan harus memenuhi syarat dari segi kualitas maupun kuantitasnya. Secara kualitas, air harus tersedia pada kondisi yang memenuhi syarat kesehatan. Kualitas air yang digunakan sebagai air minum, sebaiknya memenuhi persyaratan secara fisik, kimia, dan mikrobiologi. Air yang berkualitas baik, harus memenuhi persyaratan fisik, yaitu tidak berwarna, memiliki temperatur sama dengan temperatur udara $\left(20^{\circ} \mathrm{C}-26^{\circ} \mathrm{C}\right)$, rasanya tawar, tidak berbau, jernih atau tidak keruh, serta tidak mengandung zat padatan. Kualitas air tergolong baik, jika memenuhi persyaratan kimia yaitu $\mathrm{pH}$ Netral $(\mathrm{pH}=7)$, tidak mengandung bahan kimia beracun, tidak mengandung garam atau ion- ion logam, kesadahan rendah, dan tidak mengandung bahan organik. Persyaratan mikrobiologis yang harus dipenuhi oleh air adalah tidak mengandung bakteri patogen dan tidak mengandung bakteri nonpatogen.

\section{D.2 Optimalisasi Pemanfaatan Faktor Produksi}

Produksi adalah suatu aktivitas dalam perusahaan industri berupa penciptaan nilai tambah dari input menjadi output secara efektif dan efisien sehingga produk sebagai output dari proses penciptaan nilai tambah itu dapat dijual dengan harga yang kompetitif di pasar global (Vincent Gaspersz, 2011, 213). Produksi merupakan fungsi pokok di dalam setiap organisasi. Prinsip optimalisasi penggunaan faktor produksi pada prinsipnya adalah bagaimana menggunakan faktor produksi secara efektif dan efisien. Pengertian efisien ini dapat digolongkan menjadi tiga, yaitu efisiensi teknis, efisiensi harga (alokatif) dan efisiensi ekonomis. Penggunaan faktor produksi dikatakan efisien secara teknis, jika faktor produksi yang dipakai menghasilkan produksi yang maksimal. Efisiensi harga dicapai, jika Nilai Produk Marginal (NPM) sama dengan faktor produksi yang bersangkutan (NPMx = Px). Efisiensi ekonomis dicapai, jika usaha yang dilakukan mencapai efisiensi teknis dan efisiensi alokatif (harga) sekaligus.

\section{D.3 Peluang Usaha}

Peluang atau kesempatan adalah sesuatu yang bisa diolah/dimanfaatkan, sehingga menghasilkan uang. Kickul/Gundry (2007), memahami peranan pemikiran yang 
kreatif dan perilaku sebagai wirausaha, adalah menemukan dan menjaring peluang kewirausahaan.

Timmons/Spinelli (2007), peluang adalah "jantungnya proses kewirausahaan". Wirausaha dan investor yang sukses, mengetahui bahwa ide yang bagus bukan berarti peluang yang bagus. Timmons menjelaskan empat tonggak dasar menghadapi peluang:

a. Menciptakan atau menambah nilai pada pelanggan atau konsumen akhir.

b. Memecahkan masalah penting.

c. Tanggap terhadap pasar.

d. Dekat pada pemilik dan tim manajemen.

Katz/Green (2011), orang yang memiliki usahanya sendiri dihadapkan pada "peluang yang besar" tidak hanya untuk meningkatkan hidup dan kesejahteraannya, tapi juga untuk meningkatkan ekonomi dan masyarakat.

Peluang atau kesempatan merupakan celah/perbedaan/gap antara yang seharusnya (ideal maksimal) dan yang sebenarnya (kenyataan/fakta). Peluang yang datang ditanggapi secara berbeda oleh setiap orang, ada yang aktif dan bahkan pro-aktif, tapi ada juga yang biasa-biasa saja. Peluang berada dimana-mana dan munculnya bisa kapan saja. Cara menemukan peluang usaha bisa dengan pendekatan permintaan, bisa juga dengan pendekatan penawaran.

\section{D.4 Kelayakan Bisnis}

Studi Kelayakan Bisnis (SKB), adalah suatu pengkajian tentang layak tidaknya suatu bisnis (proyek) dilaksanakan. Layak tidaknya, berarti bisa tidaknya suatu investasi dilaksanakan dan memberikan keuntungan di kemudian hari (materi/non materi).

Husen Umar (2005), Studi Kelayakan Bisnis merupakan penelitian terhadap "rencana bisnis" yang tidak hanya menganalisis layak atau tidaknya suatu bisnis dibangun, tetapi juga saat dioperasionalkan secara rutin, dalam rangka pencapaian keuntungan yang maksimal untuk waktu yang tidak ditentukan, misalnya rencana peluncuran produk baru.

Aspek-aspek Studi Kelayakan Bisnis meliputi aspek teknis, aspek pasar dan pemasaran, aspek yuridis, aspek manajemen, aspek lingkungan dan aspek Tahap penyusunan Studi Kelayakan Bisnis terdiri dari penemuan ide, tahap penelitian, tahap evaluasi, tahap pengurutan usulan yang layak, tahap rencana pelaksanaan, tahap pelaksanaan proyek.

Analisis aspek pasar pada prinsipnya bertujuan untuk mengetahui luas pasar, pertumbuhan permintaan, dan market share produk bersangkutan.

Kondisi persaingan antar produsen dan siklus hidup produk juga penting untuk dianalisis. Ruang lingkup kegiatan analisis pasar dapat dikelompokkan dalam empat kegiatan yaitu analisis Produk-Pasar, analisis permintaan, analisis penawaran, analisis kesempatan pasar (peluang) finansial.

Studi aspek teknis dan teknologi akan mengungkap kebutuhan apa yang diperlukan dan bagaimana secara teknis proses produksi akan dilaksanakan. Tujuan studi aspek ini adalah untuk meyakini apakah secara teknis dan pilihan teknologi, rencana bisnis dapat dilaksanakan secara layak atau tidak, baik pada saat pembangunan proyek maupun operasional secara rutin.

Studi aspek keuangan bertujuan untuk mengetahui perkiraan pendanaan dan aliran kas proyek bisnis, sehingga dapat diketahui layak atau tidaknya rencana bisnis yang dimaksud. Dari sisi keuangan, proyek bisnis dikatakan sehat apabila dapat memberikan keuntungan yang layak dan mampu memenuhi kewajiban finansialnya. Kegiatan pada 
aspek keuangan ini antara lain adalah penghitungan perkiraan jumlah dana yang diperlukan untuk keperluan modal kerja awal dan untuk pengadaan harta tetap proyek, dipelajari pula struktur pembiayaan yang paling menguntungkan dengan menentukan berapa dana yang harus disiapkan lewat pinjaman dari pihak lain dan berapa dana dari modal sendiri. Hasil analisis keuangan akan digunakan untuk mengkomunikasikan keadaan rencana keuangan dengan pihak yang berkepentingan. Ada beberapa metode analisis dalam aspek keuangan, untuk analisis kelayakan finansial bisnis diantaranya adalah Payback Period, Net Present Value (NPV), Profitability Index (PI), dan Internal Rate of Return (IRR).

Tujuan studi aspek manajemen adalah untuk mengetahui apakah pembangunan dan implementasi bisnis dapat direncanakan, dilaksanakan, dan dikendalikan, sehingga rencana bisnis dapat dinyatakan layak atau sebaliknya.

Titik tolak untuk melakukan analisis dalam menyusun studi kelayakan bisnis, dibutuhkan informasi lingkungan luar perusahaan untuk mengetahui seberapa jauh lingkungan luar tersebut memberikan peluang sekaligus ancaman bagi rencana bisnis.

Studi terhadap aspek yuridis berguna antara lain untuk kelangsungan hidup proyek serta untuk meyakinkan para kreditur dan investor bahwa proyek yang akan dibuat tidak menyimpang dari aturan yang berlaku.

\section{D.5 Kinerja Keuangan}

Analisis kinerja keuangan diukur dengan menggunakan analisis rasio keuangan yang meliputi Rasio Likuiditas (Current Ratio, Cash Ratio, Quick Ratio), Rasio Solvabilitas (Total Debt to Equity Ratio, Total Debt to Total Capital Assets), Rasio Rentabilitas (Rate of Return on Investment, Rate of Return on Net Worth, Total Assets Turnover).

\section{E. Kerangka Pemikiran}

Kerangka pemikiran penelitian ini adalah sebagai berikut:

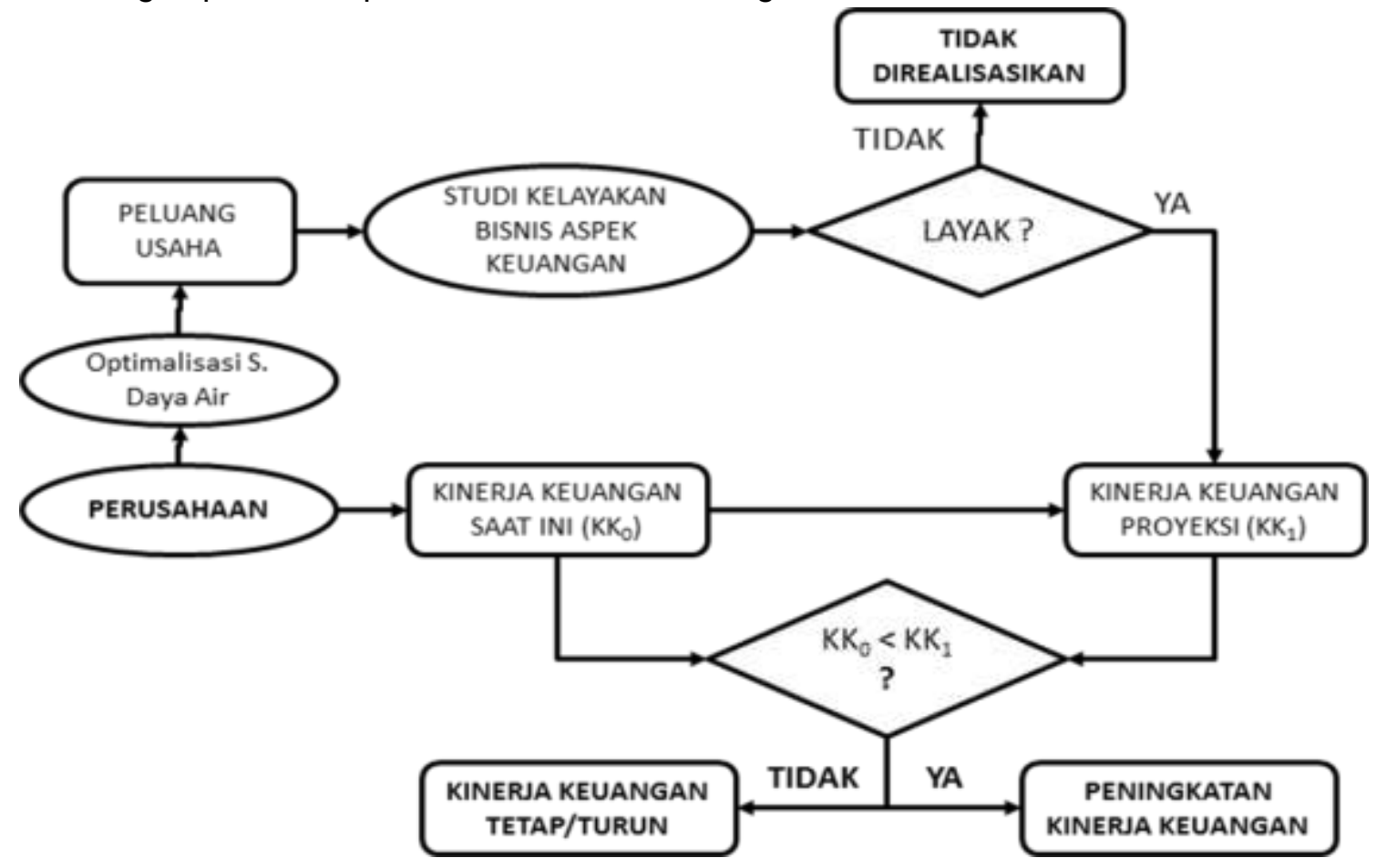




\section{F. Hipotesis}

1. Optimalisasi pemanfaatan sumber daya air berdasarkan kapasitas terpasang dengan tambahan bisnis air minum dalam kemasan galon sangat layak untuk direalisasikan berdasarkan kajian aspek keuangan.

2. Terjadi peningkatan kinerja keuangan pada perusahaan setelah adanya optimalisasi pemanfaatan sumber daya air berdasarkan kapasitas terpasang dengan tambahan bisnis air minum dalam kemasan galon.

\section{G. Metodologi}

Penelitian yang dilakukan adalah penelitian terapan, yaitu penelitian yang ditujukan untuk mencari temuan yang dapat diterapkan untuk kepentingan kehidupan manusia. Metode penelitian yang digunakan adalah Metode Deskriptif dimana peneliti berupaya mengumpulkan data, menganalisis secara kritis atas data-data tersebut dan menyimpulkannya berdasarkan fakta-fakta pada masa penelitian berlangsung atau masa sekarang.

\section{G.1 Operasionalisasi Variabel}

Operasionalisasi variabel merupakan gambaran tentang bagaimana suatu variabel diukur. Hal ini ditunjukkan pada variabel-variabel yang digunakan

untuk mengukur kelayakan bisnis baru dalam aspek keuangan dan kinerja keuangan perusahaan.

\section{G.2 Sumber Data dan Informasi}

Jenis data yang diperlukan dalam penelitian ini adalah data sekunder, yang diperoleh dari studi pustaka terhadap buku-buku yang dibutuhkan dan melalui laporan posisi keuangan dan laporan rugi laba.

\section{G.3 Metode Pengumpulan Data}

Dalam penelitian ini, metode pengumpulan data yang digunakan adalah:

1. Dokumentasi yang ada diperusahaan berupa laporan keuangan yang disusun oleh CV Tirta Buana.

2. Studi kepustakaan buku-buku ilmiah, literatur dan lain sebagainya yang berhubungan dengan permasalahan yang dibahas dalam penelitian ini.

3. Interview dengan responden dalam hal ini adalah pihak perusahaan untuk mendapatkan data-data yang dibutuhkan. Interview dalam penelitian ini pada prinsipnya adalah mengkonfirmasi kepada pihak keuangan perusahaan tentang kebenaran laporan keuangan yang dibutuhkan.

\section{G.4 Metode Analisis}

Metode analisis yang akan digunakan dalam penelitian ini adalah analisis kuantitatif. Dalam penelitian ini Peneliti melakukan analisis kelayakan finansial AMDK Galon dan analisis kinerja keuangan perusahaan. 


\section{G.4.1 Analisis Kelayakan Finansial Bisnis}

Dalam analisis kelayakan finansial bisnis AMDK Galon peneliti menggunakan metode analisis Payback Period, Net Present Value (NPV), Profitability Indeks (PI), dan Internal Rate of Return (IRR).

Payback Period merupakan alat ukur pada tahap awal penilaian suatu investasi. Metode ini digunakan untuk menganalisa tingkat pengembalian modal terhadap proyek yang memiliki risiko karena modal yang telah ditanamkan harus segera dapat diterima kembali secepat mungkin.

Rumus Payback Period adalah:

$$
\text { Payback Period }=\frac{\text { Total Investasi }}{\text { Net Income }+ \text { Depresiasi }} \times 1 \text { tahun }
$$

Net Present Value (NPV) merupakan selisih antara investasi sekarang dengan nilai sekarang dari hasil-hasil bersih proyeksi transaksi yang diharapkan.

Rumus NPV adalah:

$$
\text { NPV = PV of Benefit - PV of Capital Cost }
$$

atau

$$
\begin{aligned}
\mathrm{NPV} & =\sum_{n}^{1} \frac{\mathrm{C}}{(1+\mathrm{i})^{\mathrm{n}}}+\sum_{n}^{1} \frac{-\mathrm{C}}{(1+\mathrm{i})^{\mathrm{n}}} \text { dimana: } \\
\mathrm{i} & =\text { Bunga dalam } \% \\
\mathrm{n} & =\text { periode (tahun, bulan) } \\
-\mathrm{C} & =\text { Modal (capital) } \\
\mathrm{C} & =\text { Hasil bersih (proceed) }
\end{aligned}
$$

Profitability Index (PI) mirip dengan analisis NPV. Perbedaannya adalah NPV satuan penilaiannya uang, sedangkan $\mathrm{PI}$ adalah index.

Rumus perhitungan PI adalah:

$$
\text { PI }=\frac{\text { PV of Benefit }}{\text { PV of Capital Cost }}
$$

Kriteria penilaian $\mathrm{PI}$ adalah:

Jika: $\quad \mathrm{PI}>1$, maka investasi dikatakan layak

$\mathrm{PI}<1$, maka investasi dikatakan tidak layak

$\mathrm{PI}=1$, maka investasi Break Even Point

Internal Rate of Return (IRR) adalah besarnya suku bunga yang membuat Present Value (PV) dari investasi dan hasil-hasil bersih yang diharapkan selama proyek berjalan menjadi 0 (Nol). Nilai suku bunga yang membuat Present Value $=0$ (nol) tersebut dinamakan Rate of Return. Patokan standarisasi IRR adalah suku bunga bank yang berlaku pada saat sekarang. IRR yang baik apabila lebih besar dari suku bunga bank. 
Bila proyek dibiayai sendiri maka sebagai pembanding adalah suku bunga deposito, sedangkan bila proyek dibiayai oleh pinjaman bank dan biaya sendiri sebagai patokan adalah suku bunga pinjaman, karena debitor harus mampu membayar bunga pinjaman tersebut atau disebut juga minimum attractive rate of return (MARR).

Rumus perhitungan IRR:

$$
I R R=i_{1}+\left(i_{2}-i_{1}\right) \times \mid \frac{N_{1}}{\left(N_{1} V_{1}-N_{1} V_{2}\right)} \times 100 \%
$$

dimana:

$\mathrm{NPV}_{1}$ harus diatas $0,\left(\mathrm{NPV}_{1}>0\right)$

$\mathrm{NPV}_{2}$ harus dibawah $0,\left(\mathrm{NPV}_{2}<0\right)$

\section{G.4.2 Analisis kinerja keuangan perusahaan}

Dalam analisis kinerja keuangan perusahaan peneliti melakukan perbandingan terhadap kinerja keuangan perusahaan untuk periode saat ini dengan proyeksi kinerja perusahaan setelah didirikannya bisnis baru (AMDK Galon). Disini peneliti melakukan analisis rasio keuangan yang meliputi Rasio Likuiditas (Current Ratio, Cash Ratio, Quick Ratio), Rasio Solvabilitas (Total Debt to Equity Ratio, Total Debt to Total Capital Assets), Rasio Rentabilitas (Rate of Return on Investment, Rate of Return on Net Worth, Total Assets Turnover).

Rasio Likuiditas digunakan untuk mengukur kemampuan perusahaan dalam memenuhi kewajiban jangka pendek serta menganalisis dan menginterpretasikan posisi keuangan dalam jangka pendek.

Current Ratio merupakan perbandingan antara aktiva lancar dengan hutang lancar.

Rumus Current Ratio adalah:

$$
\text { Current Ratio }=\frac{\text { Aktiva Lancar }}{\text { Hutang Lancar }} \times 100 \%
$$

Cash Ratio adalah perbandingan antara kas/bank dengan hutang lancar.

Rumus Cash Ratio adalah:

$$
\text { Cash Ratio }=\frac{\text { Kas + Bank }}{\text { Hutang Lancar }} \times 100 \%
$$

Quick Ratio adalah kemampuan untuk membayar hutang yang segera harus dipenuhi dengan aktiva lancar yang likuid.

Rumus Quick Ratio adalah:

$$
\text { Quick Ratio }=\frac{\text { Aktiva Lancar }- \text { Persediaan }}{\text { Hutang Lancar }} \times 100 \%
$$


Rasio Solvabilitas adalah rasio yang menunjukkan kemampuan perusahaan dalam memenuhi kewajiban keuangannya apabila perusahaan tersebut dilikuidasikan.

Total Debt to Equity Ratio yaitu kemampuan dari setiap rupiah modal sendiri yang dijadikan jaminan untuk seluruh hutang.

Rumus Total Debt to Equity Ratio adalah:

$$
\text { Total Debt to Equity Ratio }=\frac{\text { Total Kewajiban }}{\text { Total Modal Sendiri }} \times 100 \%
$$

Total Debt to Total Capital Assets adalah perbandingan antara jumlah hutang, baik hutang lancar maupun hutang jangka panjang, dengan jumlah modal atau aktiva.

Rumus Total Debt to Total Capital Assets adalah:

Total Debt to Total Capital Assets $=\frac{\text { Total Hutang }}{\text { Total Aktiva }} \times 100 \%$

Rasio Rentabilitas adalah rasio yang digunakan untuk mengukur kemampuan dan efektifitas manajemen perusahaan dalam menghasilkan laba atau mengukur profit yang diperoleh modal yang digunakan oleh perusahaan. Dalam penelitian ini rasio rentabilitas yang digunakan adalah:

Rate of Return on Investment (ROI) adalah perbandingan antara laba bersih sesudah pajak dengan total aktiva.

Rumus Rate of Return on Investment (ROI) adalah:

$$
\text { Rate of Return on Investment }=\frac{\text { Laba Bersih sesudah Pajak }}{\text { Total Aktiva }} \times 100 \%
$$

Rate of Return on Net Worth adalah perbandingan antara laba bersih sesudah pajak dengan jumlah modal sendiri.

Rumus Rate of Return on Net Worth adalah:

$$
\text { Rate of Return on Net Worth }=\frac{\text { Laba Bersih sesudah Pajak }}{\text { Total Modal Sendiri }} \times 100 \%
$$

Total Assets Turnover merupakan kemampuan dana dalam keseluruhan aktiva berputar dalam suatu periode tertentu.

Rumus Total Assets Turnover adalah:

$$
\text { Total Assets Turnover }=\frac{\text { Penjualan Netto }}{\text { Total Aktiva }}
$$




\section{H. Hasil dan Pembahasan}

Saat ini kapasitas air yang bisa dimanfaatkan dengan fasilitas yang sudah ada adalah $264 \mathrm{~m}^{3}$ per hari. Pemanfaatan awal dari kapasitas terpasang tersebut adalah untuk usaha air bersih perumahan. Optimalisasi pemanfaatan sumber daya air dilakukan dengan cara mengolah air baku yang selama ini hanya dialirkan ke pelanggan perumahan sebagai air bersih menjadi produk air yang memiliki nilai ekonomis lebih tinggi, yang berarti secara langsung memberikan nilai tambah ekonomis kepada air baku tersebut.

Nilai rupiah air bersih pada bisnis air bersih untuk pelanggan perumahan saat ini adalah Rp3.200,- per $\mathrm{m}^{3}$. Dengan pemakaian rata-rata pelanggan per hari adalah 350 liter berarti dengan 359 pelanggan aktif maka kapasitas air terpasang yang sudah dimanfaatkan untuk pelanggan air bersih perumahan adalah $125,65 \mathrm{~m}^{3}$ per hari atau $3.769 \mathrm{~m}^{3}$ per bulan. Berarti ada $138,35 \mathrm{~m}^{3}$ per hari atau $4.150 \mathrm{~m}^{3}$ per bulan yang belum dimanfaatkan.

Berdasarkan laporan rugi laba CV Tirta Buana pada tahun 2013, untuk melayani pelanggan perumahan dibutuhkan biaya Rp13.210.738,- per bulan, sementara pemasukan rekening bulanan dari pelanggan perumahan adalah Rp16.089.800,- per bulan. Berarti laba adalah Rp2.879.062,- per bulan dengan volume air terpakai $3.769 \mathrm{~m}^{3}$. Maka nilai ekonomis air adalah Rp0,76,- per liter.

\section{H.1 Analisis Kelayakan Bisnis}

Analisis pasar air minum dalam kemasan (AMDK) galon sangat penting dilakukan terutama untuk meramalkan (forecasting) seberapa besar permintaan pasar yang akan dipenuhi perusahaan. Jumlah proyeksi permintaan yang akan dipenuhi perusahaan tersebut dan batasan-batasan yang dimiliki perusahaan (khususnya dalam hal permodalan) akan menjadi dasar dalam menentukan tingkat produksi.

Produk yang akan dipasarkan adalah air minum dalam kemasan galon dengan kualitas reverse osmosis. Air minum dengan kualitas reverse osmosis merupakan air minum dengan tingkat kualitas satu level di atas air mineral. Air minum dalam kemasan galon dengan kualitas reverse osmosis merupakan produk konsumsi rutin harian dan merupakan barang yang tahan lama.

Perusahaan berencana untuk memasarkan produk air minum dalam kemasan galon secara bertahap ke penduduk di wilayah Kabupaten Bandung Barat, Cimahi, Kota Bandung, dan Kabupaten Bandung. Potensi calon pelanggan sangat besar jika dilihat dari jumlah penduduk di empat kabupaten tersebut berdasarkan sensus terakhir (data dari BPS Kota/Kabupaten bersangkutan), yaitu mencapai 7.870.441 pelanggan.

CV Tirta Buana akan menerapkan strategi pemasaran yang lebih terkonsentrasi di satu wilayah tertentu dahulu yang lebih dekat dengan tempat produksi. Setelah survei langsung ke wilayah potensial disekitar tempat produksi diketahui bahwa ada 5.684 rumah yang belum mengkonsumsi air minum dalam kemasan galon secara rutin, berarti ada potensi permintaan 1.624 galon per hari yang bisa dipenuhi oleh perusahaan. Jika rata-rata pemakaian minimal per rumah adalah 2 galon per minggu maka dengan promosi dan strategi harga dan pendekatan layanan yang direncanakan perusahaan optimis bisa meraih $25 \%$ dari potensi permintaan yang ada, itu berarti 406 galon per hari. Jumlah tersebut lebih dari cukup untuk memenuhi kapasitas produksi tahap awal sejumlah 350 galon per hari. 
Kapasitas produksi awal ditentukan dengan pendekatan modal bukan dengan pendekatan potensi permintaan pasar, karena pendekatan potensi permintaan pasar akan membutuhkan modal yang sangat besar.

Secara finansial, bisnis air minum dalam kemasan galon sangat layak untuk dilaksanakan. Produksi AMDK galon kapasitas 350 galon per hari atau 10.500 galon per bulan dibutuhkan air baku maksimal 14.000 liter per hari atau $420 \mathrm{~m}^{3}$ per bulan. Berdasarkan perhitungan profit loss proforma, biaya yang dibutuhkan untuk memproduksi dan menjual 8.750 galon per bulan adalah Rp20.271.944,- dengan pendapatan kotor Rp70.000.000,- per bulan. Berarti laba adalah Rp49.728.056,- per bulan. Maka nilai ekonomis air adalah Rp118,- per liter. Jadi, kapasitas air sebesar 138,35 $\mathrm{m}^{3}$ per hari yang belum dimanfaatkan akan memiiki nilai ekonomis yang jauh lebih tinggi jika diperuntukkan untuk bisnis air minum dalam kemasan galon daripada diperuntukkan untuk bisnis air bersih untuk perumahan.

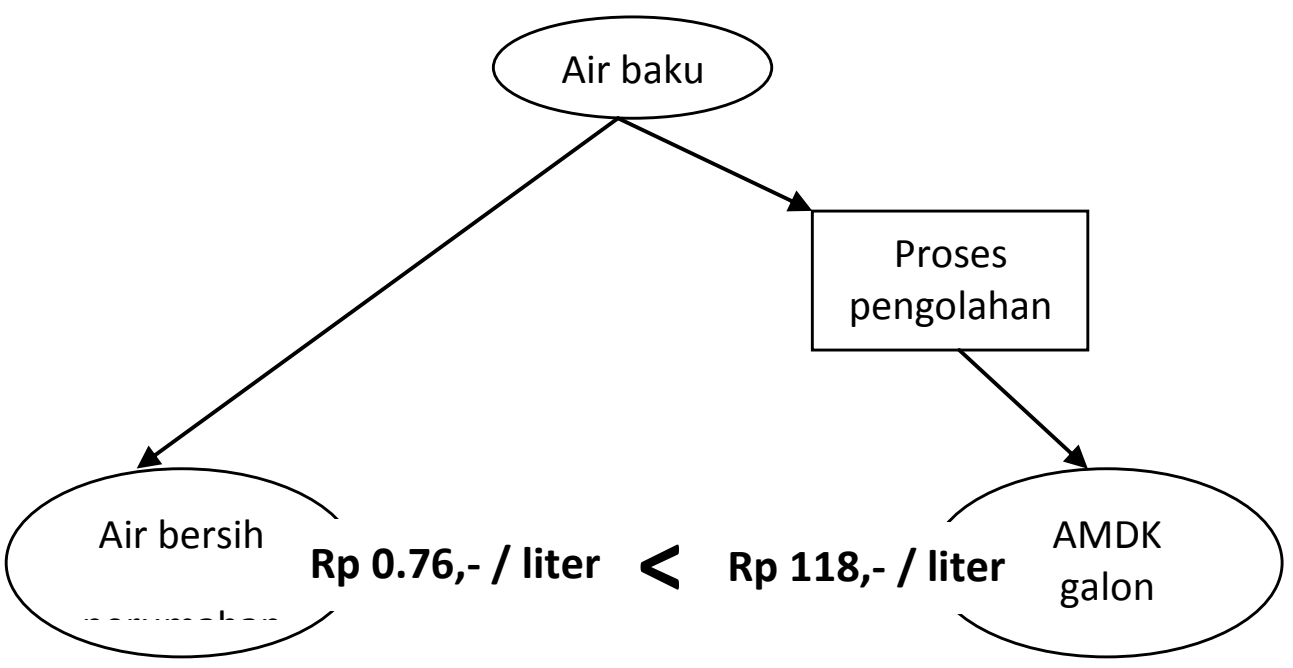

Gambar. Perbandingan nilai ekonomis air bersih perumahan dengan AMDK galon.

Berdasarkan perhitungan payback period, diperoleh bahwa posisi payback period dicapai pada bulan ke-10 dari maksimum payback period 45 bulan, berarti investasi pada usaha ini sangat layak.

Berdasarkan hasil perhitungan menggunakan konsep NPV diketahui bahwa keuntungan ekonomis dari usaha AMDK galon adalah Rp500.171.287. Jadi usaha tersebut layak berdasarkan pertimbangan ekonomi karena nilai NPV lebih besar daripada nol.

Berdasarkan hasil perhitungan menggunakan konsep PI diketahui bahwa profitabilitas indeks usaha AMDK galon adalah 1,78. Jadi usaha tersebut layak berdasarkan pertimbangan ekonomi karena nilai $\mathrm{PI}>1$.

IRR adalah besarnya suku bunga yang membuat present value dari investasi dan hasilhasil bersih yang diharapkan menjadi nol. Berdasarkan hasil perhitungan diatas dimana tingkat bunga yang dipakai adalah 90\% menghasilkan NPV sebesar 105.532.582. Berarti usaha tersebut layak berdasarkan pertimbangan ekonomi karena nilai NPV dengan tingkat suku bunga $90 \%$ masih menghasilkan nilai jauh di atas nol, sehingga dipastikan IRR lebih besar dari $90 \%$. 


\section{H.2 Kinerja Keuangan Perusahaan}

Berdasarkan data historis laporan keuangan perusahaan sampai dengan tahun 2013 mengalami penurunan. Hal ini terutama disebabkan terjadinya kenaikan biaya operasional secara signifikan dari tahun ke tahun, sementara pendapatan rutin yang cenderung tetap. Pendapatan rutin perusahaan tanpa investasi pada sub bisnis baru diproyeksikan cenderung tetap karena menaikkan tarif sebagai jalan untuk meningkatkan pendapatan tanpa menimbulkan efek samping (gejolak negatif masyarakat pelanggan) yang dapat mengganggu stabilitas perusahaan sangat sulit untuk kembali dilakukan perusahaan swasta jasa layanan air bersih manapun.

Berdasarkan data historis laporan keuangan perusahaan tahun 2010-2013 dapat diproyeksikan kinerja keuangan tahun 2014-2015 dengan tambahan bisnis AMDK galon sebagai berikut:

\section{Current ratio}

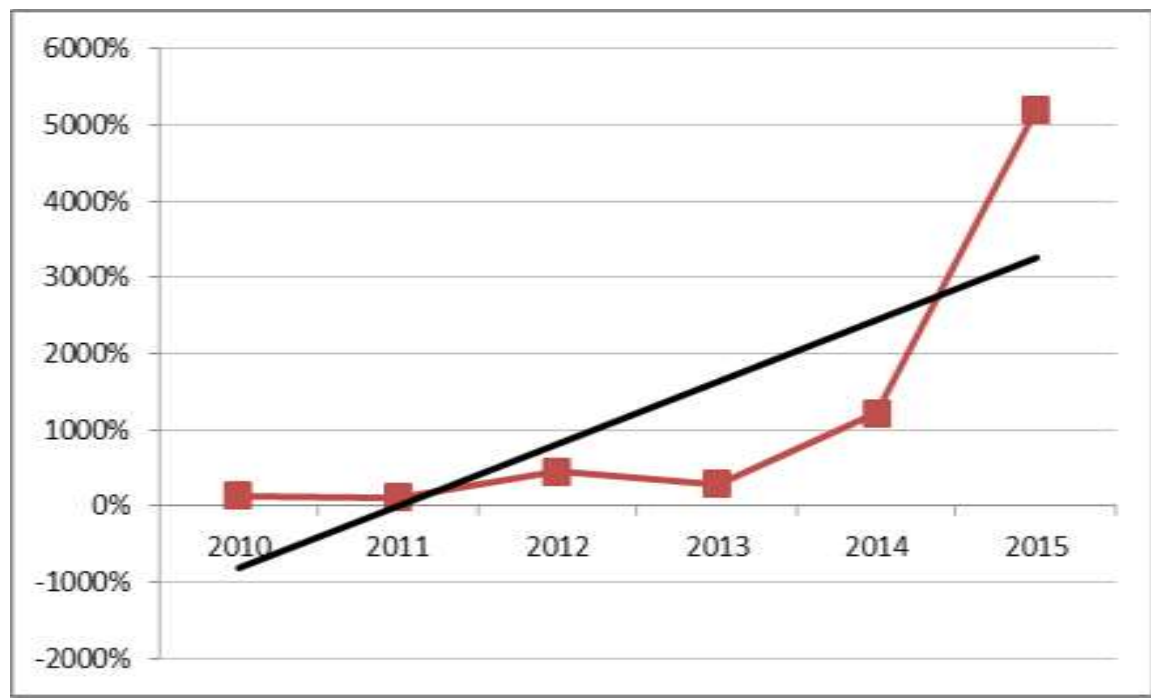

Terjadi peningkatan current ratio setelah adanya bisnis AMDK galon, hal ini berarti meningkatkan kemampuan perusahaan untuk memenuhi kewajiban jangka pendeknya dengan harta lancar yang dimilikinya.

Cash ratio

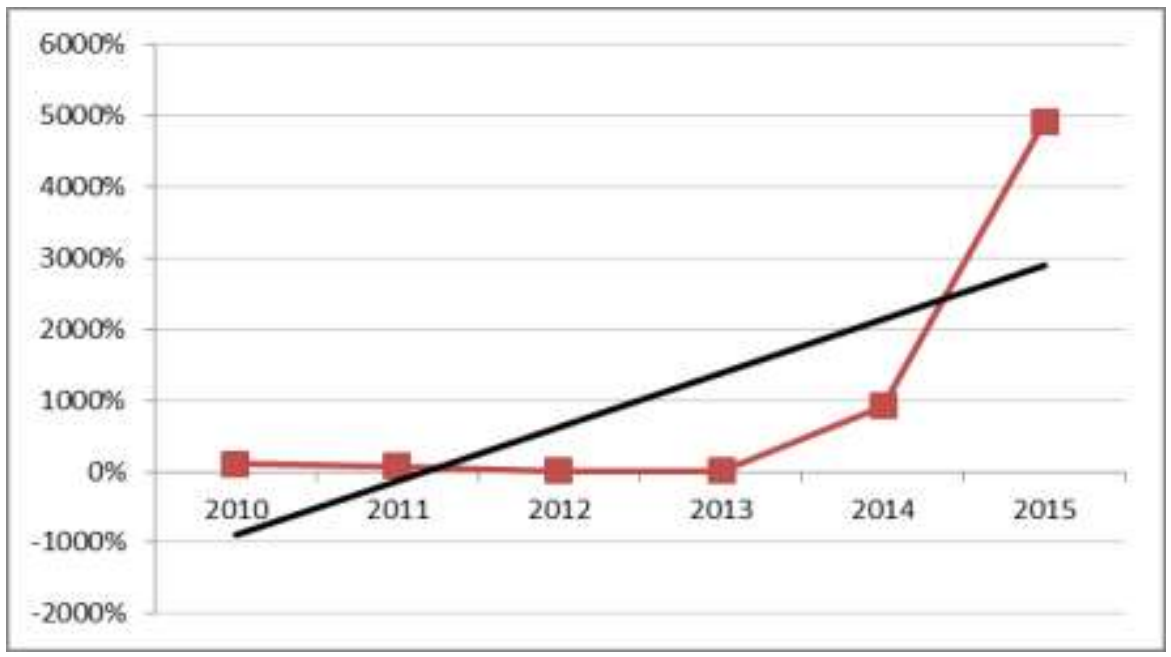


cash ratio setelah adanya bisnis AMDK galon cenderung meningkat. Hal ini berarti kemampuan perusahaan untuk memenuhi kewajiban jangka pendeknya dengan dana yang ada di kas dan bank meningkat sangat tajam.

Total debt to equity ratio

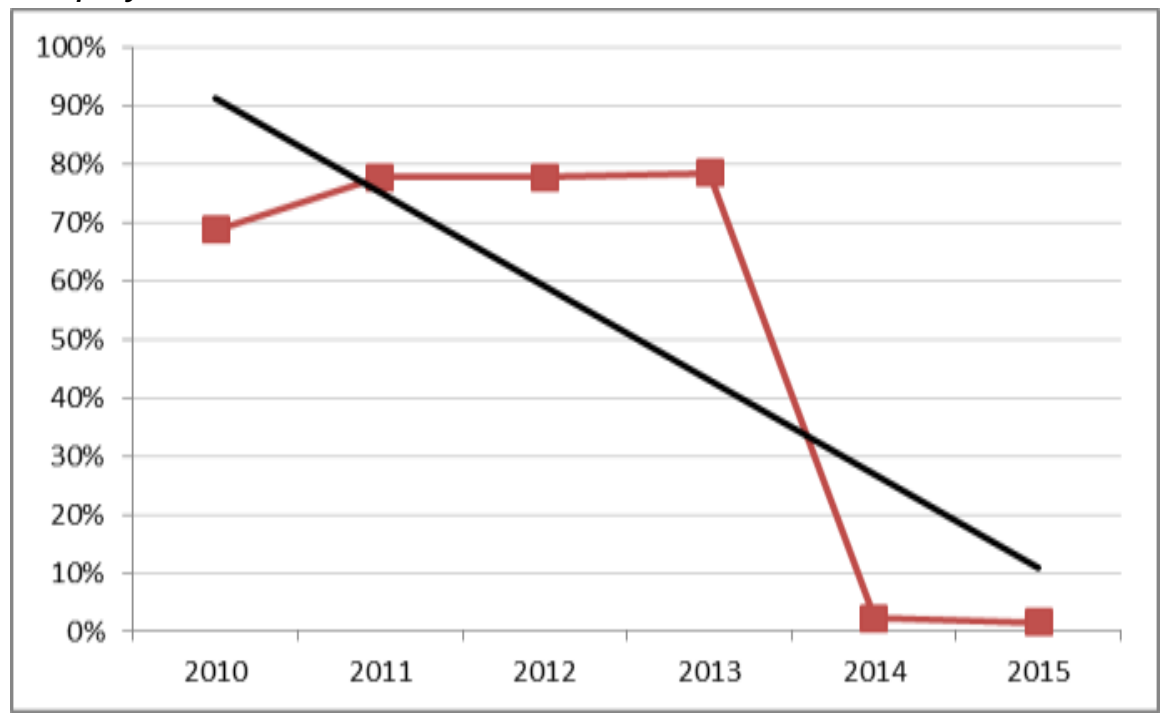

Adanya bisnis AMDK galon memberikan keuntungan yang sangat bagus sehingga total debt to equity ratio cenderung menurun bahkan sampai mendekati $0 \%$. Hal ini dimungkinkan terjadi karena keuntungan yang diperoleh perusahaan tidak hanya meningkatkan total modal sendiri tapi juga dimanfaatkan untuk membayar hutang.

Total debt to total capital assets

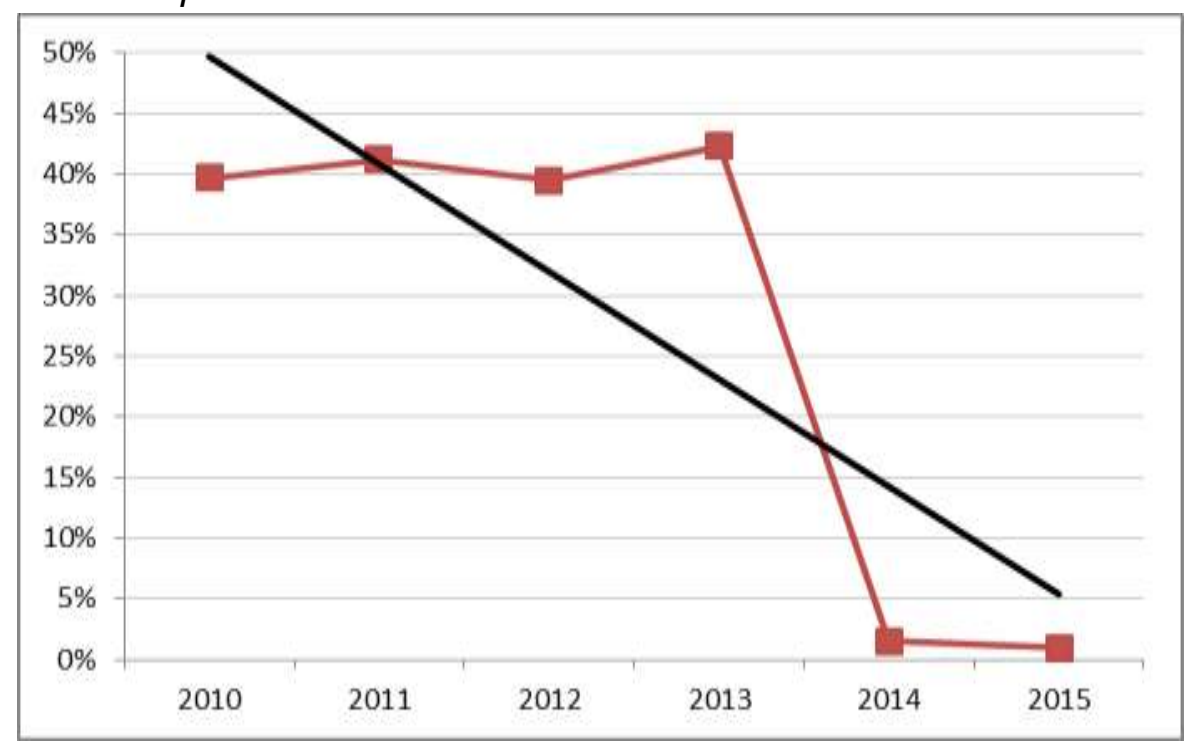

total debt to total capital assets setelah adanya bisnis AMDK galon cenderung menurun yang berarti keuntungan perusahaan secara signifikan mampu mengurangi ketergantungan perusahaan terhadap hutang. 
Rate of return on investment

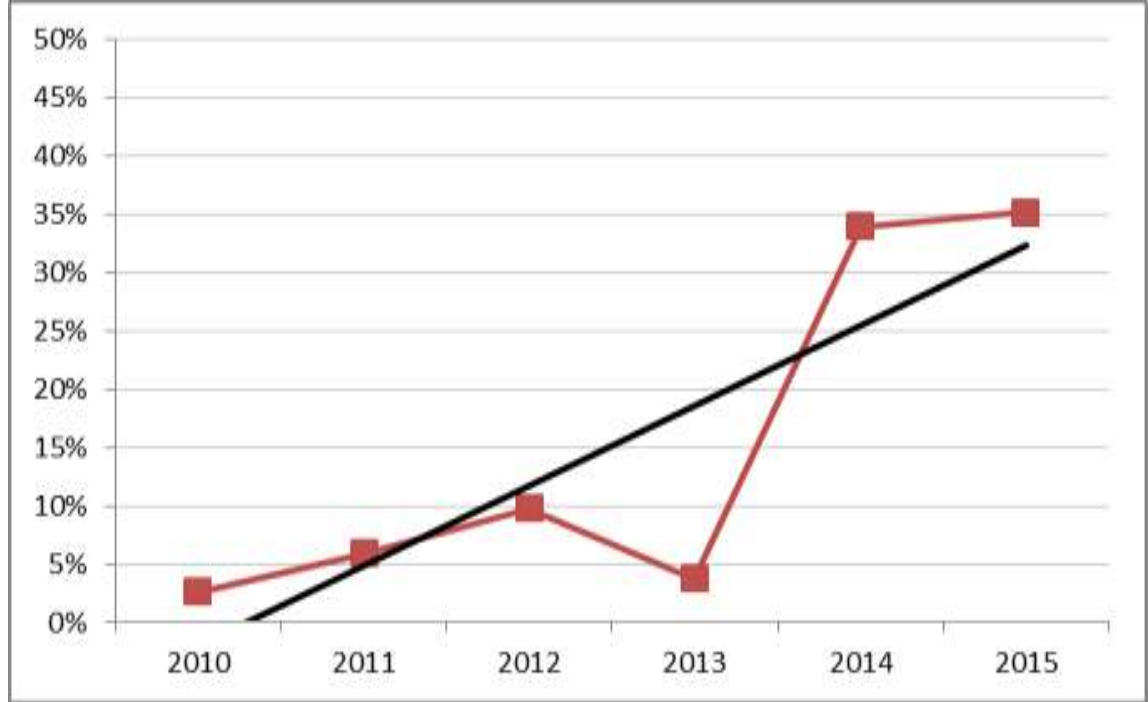

Setelah adanya bisnis AMDK galon keuntungan cenderung meningkat terhadap total aktiva sehingga rate of retun on investment cenderung meningkat.

Rate of return on net worth

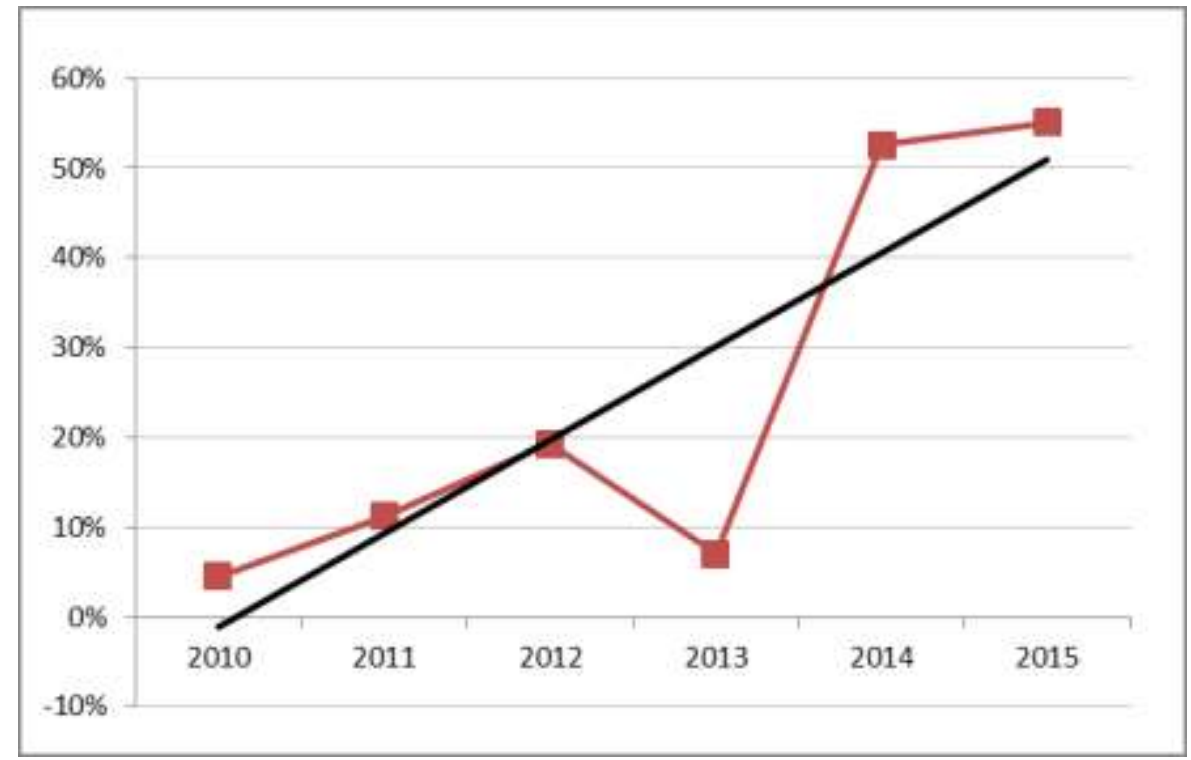

Setelah adanya bisnis AMDK galon rate of return on net worth cenderung meningkat yang berarti ada peningkatan keuntungan yang sangat bagus terhadap modal sendiri. 
Total assets turnover

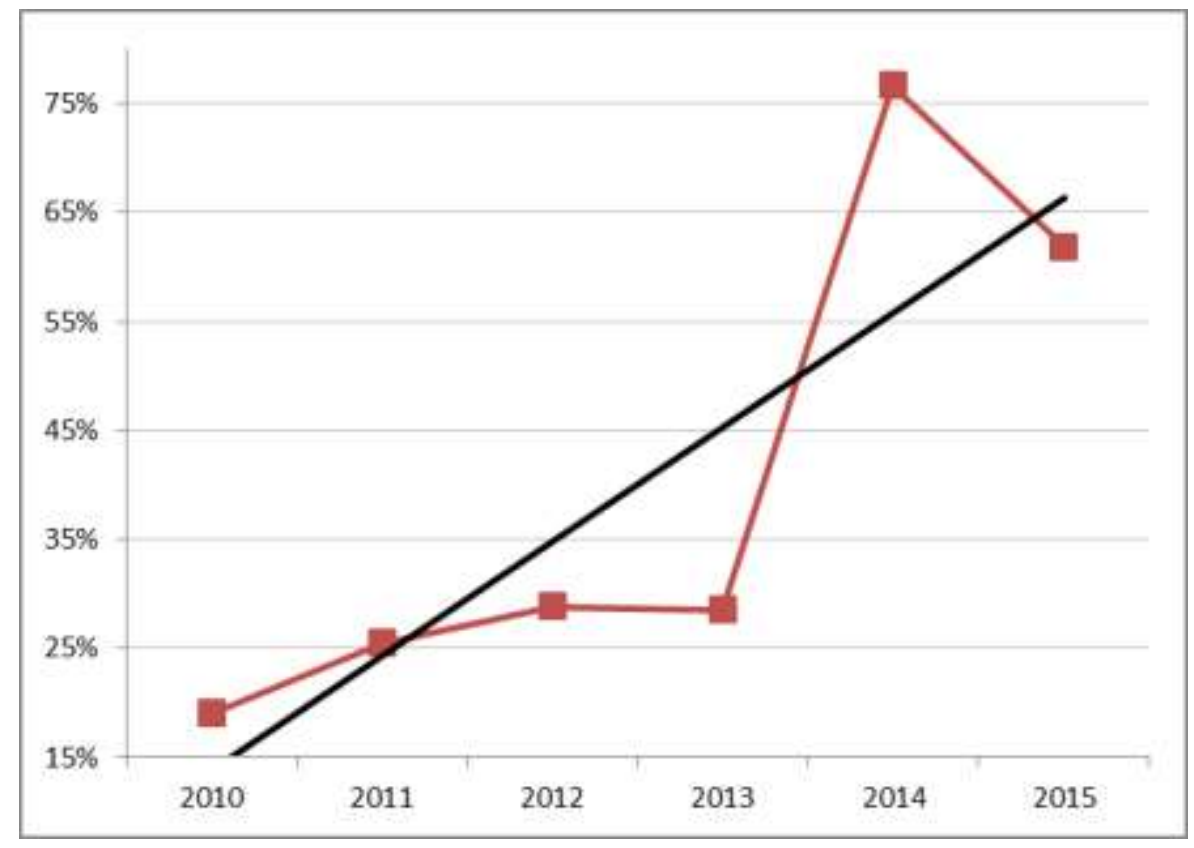

Setelah adanya bisnis AMDK galon total assets turnover cenderung meningkat lebih tinggi yang diikuti oleh jumlah pendapatan total dan aset yang jauh lebih besar.

\section{Kesimpulan dan Saran} dilakukan:

Beberapa hal yang dapat penulis simpulkan berdasarkan analisis yang telah

1. Optimalisasi pemanfaatan sumber daya air berdasarkan kapasitas terpasang dengan mendirikan bisnis air minum dalam kemasan galon sangat layak direalisasikan, khususnya berdasarkan kajian aspek keuangan yaitu Payback Period 10 bulan dari batas maksimum 45 bulan, NPV $=500.171 .287, \mathrm{PI}=1,78$ dan IRR > 90\%. Optimalisasi juga sangat tepat dilakukan, karena dapat meningkatkan nilai ekonomis sumber daya air yang dari Rp0.76,- per liter (bisnis air bersih perumahan) menjadi Rp118,-

2. Bisnis air minum dalam kemasan galon dapat meningkatkan kinerja keuangan CV Tirta Buana secara signifikan, hal ini dapat dilihat dari peningkatan current ratio, peningkatan cash ratio, penurunan total debt to equity ratio, penurunan total debt to total capital assets, peningkatan rate of return on investment, peningkatan rate of return on net worth, dan peningkatan total assets turnover.

Studi kelayakan bisnis air minum dalam kemasan galon dan kajian aspek keuangan dalam upaya untuk menjaga dan meningkatkan kinerja keuangan perusahaan diharapkan tidak berhenti setelah penelitian ini selesai, tetapi dapat dilanjutkan dan direvisi terus seiring dengan perubahan di dalam dan di luar lingkungan perusahaan. Perubahan yang terjadi dapat berupa perubahan strategi bisnis perusahaan, ataupun munculnya perkembangan teknologi baru yang dapat dipertimbangkan CV Tirta Buana untuk meningkatkan kinerjanya. Beberapa saran sebagai implikasi manajerial yang dapat diberikan antara lain: 
1. Berkenaan dengan potensi pasar yang sangat besar dan kapasitas sumber daya air terpasang yang masih menyisakan 3.349.500 liter setiap bulannya, disarankan untuk terus mengembangkan kapasitas produksi air minum dalam kemasan galon secara bertahap sampai mencapai kapasitas produksi 2.800 galon per hari.

2. Keseimbangan antara kapasitas produksi dengan target penjualan sangat penting agar tidak terjadi inefisiensi, peningkatan bertahap kapasitas produksi sebaiknya dikuti dengan pengembangan bertahap wilayah target pemasarannya yang disesuaikan dengan pengembangan kapasitas produksi tersebut.

3. Pasar air minum dalam kemasan tidak hanya dalam kemasan galon, tapi ada kemasan lainnya (botol dan cup). Pengembangan produk air minum dalam kemasan botol dan cup bisa membantu memperluas segmen pasar yang menjadi target pemasaran perusahaan.

4. Perubahan lingkungan internal maupun eksternal perusahaan bisa sangat mempengaruhi rencana yang sudah dibuat perusahaan, jadi perusahaan disarankan terus melakukan penyesuaian- penyesuaian terhadap studi kelayakan bisnis AMDK galon, disesuaikan terhadap perkembangan-perkembangan baru yang terjadi baik di dalam lingkungan perusahaan maupun di luar perusahaan.

5. Teknologi bisa sangat mempengaruhi daya saing perusahaan, jadi perusahaan disarankan terus memantau perkembangan teknologi yang berhubungan dengan pengolahan air minum dalam kemasan, khususnya teknologi mengenai filterisasi dan sterilisasi air bak.

\section{J. Daftar Pustaka}

Arsyad, Lincoln. 2008. Ekonomi Manajerial. Yogyakarta. BPFE-YOGYAKARTA.

Baye, Michael R. 2010. Managerial Economics and Business Strategy. McGraw-Hill International.

Bedworth, David D nd Bailey, James E. 1987. Integrated Production Control Systems: Management, Analysis, Design. John Wiley \& Sons.

Bygrave, William and Zacharakis, Andrew. 2008. Entrepreneurship. John Wiley and Sons.

Dilworth, James B. 1992. Operations Management: Design, planning, and Control for Manufacturing and Services. McGraw-Hill Book Co.

Douglas, Evan J. Managerial Economics: Analysis and Strategy. New Jersey. PrenticeHall.

Effendi, Hefni. 2003. Telaah Kualitas Air, Bagi Pengelolaan Sumber Daya dan Lingkungan Perairan. Yogyakarta. Kanisius.

Fahmi, Irham. 2012. Analisis Kinerja Keuangan. Bandung. Alfabeta.

Fauzi, Akhmad. 2004. Ekonomi Sumber Daya Alam dan Lingkungan, Teori dan Aplikasi. Jakarta. PT Gramedia Pustaka Utama. 
Gasperzs, Vincent. 2011. Ekonomi Manajerial. Jakarta. PT Percetakan Penebar Swadaya

Griffin, Ricky W and Ebert, Ronald J. 2006. Bisnis. Pearson Education, Inc.

Hisrich, Robert and Shepherd, Dean. 2005. Entrepreneurship. New York. McGraw-Hill.

Nardi Sunardi (2017), Pengaruh Intelectual Capital (iB-VAICTM), FDR dan CAR terhadap Efisiensi Biaya dan Implikasinya pada Kinerja Perusahaan Bank Umum Syariah Indonesia Priode 2012-2016, Jurnal Sekuritas (Saham, Ekonomi, Keuangan dan Investasi), ISSN (online) : 2581-2777 \& ISSN (print) : 2581-2696, Vol.1, No.1.

Katz, Jerome A and Green II, Richard P. 2011. Entrepreneurial Small Business. New York. McGraw-Hill Companies, Inc.

Kickul, Jill R and Gundry, Lisa K. 2007. Entrepreneurship Strategy. SAGE Publications.

Kotler, Philip and Keller, Kevin L. 2009. Marketing Management, Thirteenth Edition. Pearson Education, Inc.

Kuratko, Donald F. 2012. Entrepreneurship: Theory, Process, Practice. South-Western Cengage Learning.

Kusnaedi. 2010. Mengolah air kotor untuk air minum. Bekasi. Penebar Swadaya.

Lambing, Peggy and Kuehl, Charles R. 2000. Entrepreneurship. New Jersey. PrenticeHall.

Landstrom, Hans. 2006. Entrepreneurship, Sustainable Growth and Performance. Edward Elgar Publishing.

Longenecker, Justin G and Petty, J. William. 2009. Small Business Management: Launching and Growing Entrepreneurial Ventures. South-Western Cengage Learning.

Madura, Jeff. 2007. Pengantar Bisnis. Jakarta. Salemba Empat.

Pramiyanti, Alila. 2008. Studi Kelayakan Bisnis Untuk UKM. Yogyakarta. Media Pressindo

Sugiama, A Gima. 2008. Metode Riset Bisnis dan Manajemen. Bandung. CV Guardaya Intimarta

Zimmerer, Thomas W and Scarborough, Norman M. 2008. Kewirausahaan dan Manajemen Usaha Kecil. Jakarta. Salemba Empat. 